\title{
Restoring Democracy: Australian Responses to Military Coups in Fiji
}

\author{
Andrew Kelly \\ School of Humanities and Communication Arts \\ University of Western Sydney \\ andrew.kelly@uws.edu.au \\ DOI: https://doi.org/10.32890/jis2015.11.1
}

\begin{abstract}
This article examines Australian responses to successive military coups in Fiji as well as the 2014 Fijian election. In each of Fiji's three military coups, Australia failed to strike an appropriate balance between simultaneously condemning these military takeovers and taking positive steps toward restoring Fiji to normal democratic processes. Accordingly, this article argues that Australia has habitually viewed Fiji's military coups through a broader strategic lens which has done little to encourage political change in Suva. Recent positive steps by the Abbott government to normalise relations and assist with Fiji's 2014 election inspired some degree of confidence about the future of Fiji and its relationship with Australia. Nevertheless, for Australia to find long-term stability in Fiji, the Abbott government must learn from past mistakes, tread cautiously, and encourage stronger dialogue between the two countries.
\end{abstract}

Keywords: Military coup, restoring democracy, parliament democracy.

\section{Introduction}

After decades of political instability, military takeovers and subsequent international condemnation, Fiji successfully conducted a landmark election in September 2014 that restored democratic processes to the small island nation. Calls for such a move by Australiaarguably the most influential regional actor responsible for maintaining peace throughout the South Pacific — have been loud and consistent ever since Military Commander Frank Bainimarama led a coup in December 2006 that overthrew the sitting parliament and placed Fiji under military rule. Australia's involvement in Fiji-and, for that matter, the greater South Pacific - has been pillared on democratic promotion. This is based on concerns over a Pacific "arc of instability" that threatens the peace of the region, prompting successive Australian governments to call for a restoration of democracy after each of Fiji's coups in 1987, 2000 and 2006 (Ayson, 2007; Rumley, 2006; Duncan \& Chand, 2002). For Canberra, anything less than a return to democracy in Fiji threatened the stability of its immediate neighbourhood and weakened Australia's credentials as a major power capable of maintaining stability in the South Pacific. 
Andrew Kelly

To that end, a peaceful, democratic Fiji has always been in Australia's national interest. Yet, as successive Australian governments have responded to military coups in Fiji, there has been a tendency to look beyond what specific measures might best help Fiji in restoring democracy and finding long-term stability in its political processes. In other words, this article argues that Australia, to its own detriment, has habitually viewed Fiji's military coups through a broader strategic lens that has done little to encourage political change in Suva. In so doing, it builds on recent examinations into the links between Australia, democratic promotion and policies toward post-coup Fiji, as well as the idea that Australian policy visà-vis Fiji has been guided "less by democratic principle than by strategic concern" (Kumar, 2013; Firth, 2013). If the current Abbott government hopes to see significant improvement in the impact of its own policies on Fiji's turbulent political situation, it must look at Fiji's specific needs more closely, see what confidence building measures Australia might offer Fiji in order to repair the already fragile bilateral relationship, and acknowledge that past condemnations have not achieved Australian objectives. It is no secret that Australia's past "tough-love" diplomacy, particularly in the wake of the 2006 coup, "manifestly failed" in its goal to pressure Bainimarama to hold elections (Hayward-Jones, 2011).

This article first revisits the Australian response to the 1987 and 2000 Fijian Coups and provides a contextual framework for understanding the situation after the 2006 military coup. In each of these crises, Australia failed to strike an appropriate balance between simultaneously condemning a military takeover and taking positive steps toward encouraging Fiji to restore normal democratic processes. Next, it re-examines Australian Foreign Minister Bob Carr's approach to Fiji in 2012 and 2013-often hailed as the turning point in normalising Australian-Fijian relations-by particularly drawing upon his recently published diary entries. Finally, this article examines the Abbott government's recent efforts to normalise relations with Fiji and assist in staging the 2014 election. Recent Australian policy has been more productive in repairing the fragile Australian-Fijian relationship. Nevertheless, for Australia to find long-term stability in Fiji, the Abbott government must learn from past mistakes, tread cautiously, and encourage stronger dialogue between the two countries.

\section{The Fijian Military Coups}

After the British granted its independence and agreed to its first constitution in 1970, Fiji has suffered a drastic series of political changes that challenged democratic rule on the island. Its political system has generally oscillated between parliamentary democracy and military takeovers, usually in response to racial tensions between Native Fijians, IndoFijians and their respective ties to major political parties. These "ethnic schisms" have generally "provided the key catalyst to the coups," earning Fiji an unwantedly notorious reputation for being one of the most coup-prone countries in the Asia-Pacific region (Fraenkal, 2013). Alongside Fiji's fractured recent political history, Australia has also had a long and vested interest in Fijian politics. As a major power in the South Pacific, Australia 
uses its regional influence to combat military takeovers through economic and political sanctions. Australian efforts have not always been effective in encouraging political change in Fiji. To the contrary, responses have generally been harsh and condemnatory, often to the point where Australia has isolated Fiji rather than encouraging the military to return to normal democratic processes.

\section{The First Military Coup of 1987}

Fiji's first military coup came in May 1987. A coalition government between the National Federation Party (NFP) and the Fiji Labor Party (FLP) was overthrown shortly after it won the national election in early April by Lieutenant Colonel Sitiveni Rabuka and the Royal Fiji Military. The coup began on the morning of 14 May when Rabuka stormed the Fijian parliament with several other soldiers and urged a calm evacuation of Prime Minister Timoci Bavadra and the rest of his government. This ultimately set in motion a complete takeover of the newly elected coalition (Lal, 2010). For the Australian government, led by Prime Minister Bob Hawke, the coup presented an unwelcome dilemma. Australia could not support a non-elected government, nor could it apply too much pressure on an already fragile nation. Strong economic and political sanctions could worsen the situation and thereby counteract any hope for a peaceful return to parliamentary democracy.

The coup, however, did not come as a complete surprise to Australia. Fiji had shown recent signs of instability through growing dissatisfaction with Kamisese Mara's Alliance Party government, which had been in power since 1966. Racial tensions rose once the NFP-LFP Coalition came into power, which consequently brought about Rabuka's military challenge. As Australian Senator Robert Wood said, "no one denies that there were racial tensions in Fiji, but these racial tensions were deliberately inflamed to create a vehicle for the coup ... the coup was ten years in the making" (Senate Debates, 1987).

Hawke viewed the crisis through a broader strategic lens. For Australia, Fiji was a central telecommunication centre for the entire South Pacific. The major cables running through the island group "carried ten to thirty percent" of trans-Pacific telecommunications traffic to North America (Kumar, 2013). Fiji, in comparison to other island nations, also had strong diplomatic representation in the United Nations and in the past had collaborated often with Australia. Any hostile government potentially threatened these benefits, so Australia had to tread cautiously as to not aggravate Rabuka and the Fijian military too excessively.

On both sides of the Australian Parliament, opinion was unanimous that the military coup was unconstitutional and urged Fiji toward a speedy return to its normal democratic process. Differences emerged, however, on how this might be done. Hawke and his Cabinet faced strong criticism from the Liberal opposition, accusing the government of neglecting the South Pacific at a time when USSR and Libyan strategic and economic interest in the region was causing considerable concern. Just three months earlier, Defence Minister Kim Beazley 
Andrew Kelly

described the South Pacific as "fundamental to Australia's strategic well-being," although many in opposition still suggested that the Hawke government lacked a clear strategy for its approach to the region.

The Fijian military coup further ignited these concerns and become a shining example of the potential costs of Australia's lack of interest in the region. At this point, Australian concerns were greatest for losing its influence in the region in the face of strategic competition from the USSR and Libya, rather than the stability of Fiji. Criticisms were part of an attack on Hawke's South Pacific policy rather than being soft on Fiji itself.

In any case, Hawke and his Foreign Minister Bill Hayden took a cautious approach to the crisis. The situation was largely unprecedented. Beazley and many opposition ministers called for military intervention, yet such a move would have been controversial and potentially disastrous. It would also establish an undesirable precedent that Australia was prepared to intervene militarily in the South Pacific whenever democratic processes were under threat. Foreign Minister Hayden himself outlined that:

There is an unstated assumption in ... one of the rump factions of the coalition that Australia is able to order around the affairs of countries in this region; that we can pick up the small island states by the scruff of the neck and the seat of their pants, give them a good shake and point them in the right direction ... [this approach] will be counterproductive (House of Representative Debates, 1987).

Hawke also rejected categorically that military intervention was ever a viable option. Writing retrospectively in his memoirs, he laughed off suggestions that Australia might swoop in like a "Rambo" movie and prevent military takeovers (Hawke, 1994).

Ultimately, Hawke's response was a media release that condemned the coup and urged a return to parliamentary democracy. Australia also froze its aid program for Fiji and suspended defence cooperation. Even after Rabuka abrogated the 1970 constitution and declared Fiji a Republic later that October (an act which in itself caused a second, smaller coup), the Australian response remained unchanged. Demands by the Hawke government for Rabuka to reinstate democratic processes in Fiji continued and it refused to recognise the Republic. The Australian response, however, fell short of economic sanctions, fearing that such penalties would be "difficult to retrieve and likely ... to damage permanently the economic welfare of all Fiji citizens" (Prime Minister's Office, 1987).

\section{The Commonwealth and US Stand on Fiji's Coup}

The Commonwealth was equally unimpressed by Rabuka's military takeover, although the general consensus was that it must find a way to work effectively with the new Republic. At a Commonwealth meeting in Vancouver during October, delegates agreed that although 
Fiji's military involvement in political affairs and its subsequent takeover was inherently wrong and unconstitutional, they "had to live with Fiji and deal with the authority in power" (Brown, 1987). Facing criticism for neglecting the South Pacific at home, Hawke agreed that the Commonwealth must work with the new Republic. Australia had to show at least some degree of compatibility with general Commonwealth opinion, even if Australian views toward Fiji and the South Pacific compelled the Hawke government to take a stronger stance against the military takeover prior to the meeting in Vancouver. In the face of both domestic and international pressure, Hawke suggested that eventually his government would recognise Rabuka's regime, but only if "it survived and holds elections under a new constitution" (Hywood, Sargent, \& Williams, 1987). It was certainly not an ideal response, but Commonwealth views had the determining impact on Australian policy.

For Hawke, international opinion and general stability seemed to be more important than Fijian democracy. This lay at least in part to Fiji's strategic importance. On top of Commonwealth concerns, the United States had a vested interest in a stable Fiji, even if such stability was not yet realistically attainable through democratic processes. Fiji was one of the only Pacific locations where the US Navy could harbour warships without fear of nuclear bans (Kumar, 2013). It was thereby important for Australia to keep these ports open for American naval vessels, and this was most likely when Australia-Fiji relations were on amicable terms. As the South Pacific was one of the few regions where Australia could claim major power status, it was determined to demonstrate to the United States that it was holding up its share of the responsibility in maintaining peace in the Asia-Pacific. In his own words, Hawke was "keen to demonstrate to the US and the Commonwealth nations that [Australia] was providing leadership in the Pacific" (Sargent and Davies, 1987). Australia's international reputation and broader strategic interests always trumped whether Fiji was democratic or not.

\section{The Coup of 2000}

After the dust settled from the chaos in 1987, political tensions eased during the 1990s. There was, however, a greater awareness that Rabuka's coup had not only isolated many Fijians (especially the Indo-Fijians, many of which migrated to Australia, New Zealand and the United States) but had also put a significant strain on the Fijian economy. Foreign investment into Fiji had dropped and a significant portion of Fiji's qualified workforce left the country in search of opportunities elsewhere. Major political parties, including the NFP and LFP, were severely unhappy with the deteriorating situation and with the enforced constitution that came into effect in 1990 after the 1987 coup. Collaborating with NFP Leader Jai Ram Reddy, Rabuka ultimately agreed to a new constitution in 1997 which encouraged a multi-ethnic government through a preferential voting system and outlined plans for power-sharing in Cabinet. An election in May 1999 ensued but the FLP-led by Mahendra Chaudhry, who accused the NFP opposition of cooperating with the instigator of the 1987 coup — won in a landslide. Chaudhry was the first Indo-Fijian to ever hold 
Andrew Kelly

office in Fiji, a feat that again intensified racial tensions between the Native and Indo-Fijian communities. One year later, Chaudhry's government was ousted by a group of native Fijian extremists led by George Speight. Speight's groups were eventually arrested, but the Fijian military thought that their actions justified another government takeover in order to restore stability.

As expected, the international reaction to further political instability and military involvement in Fijian political affairs was not welcoming. In June 2000, as a direct result of the recent military takeover, Fiji was suspended temporarily from the Commonwealth. In Australia, Prime Minister John Howard-who was Opposition Leader when Fiji's first coup occurred in 1987-followed his previous stance against military rule, condemning both Speight's group and the military for overthrowing a fairly elected government.

However, broader concerns over instability in the South Pacific ignited when a militarised group in the Solomon Islands also forced its Prime Minister to step down in favour of its own appointee. Howard's subsequent response was not specific to each country, opting rather to address the growing concern over a "coup culture" in the South Pacific through a regional framework. This came in the form of the Biketawa Declaration, where signatories including Fiji - committed to good governance, individual liberties and equal rights. ${ }^{1}$ Again, policy toward Fiji became part of a broader South Pacific strategy rather than tailored to its own needs, and again, Australia was perhaps too short sighted in realising the example Fijian politics set for other South Pacific countries.

\section{The Coup of 2006}

Fiji experienced another military coup in December 2006 when Military Commander Frank Bainimarama overthrew the sitting Fijian parliament, declared a "state of emergency" and sought to reorganise the government under military rule with himself as leader, first as President and then as Prime Minister. According to Bainimarama, his original impetus was to abolish corruption in the Fijian parliament under the construct of the current constitution. "The RFMF (Royal Fijian Military Forces) could have carried out unconstitutional and illegal activities but has not done so and will not do so," Bainimarama announced to the Fijian public on the evening of the coup on 5 December, "[the RFMF] believes in the rule of law and adheres to the constitution" (Bainimarama, 2006). Yet once the Fiji Court of Appeal ruled in April 2009 that his seizure of power was unconstitutional, Bainimarama enforced a full-scale military takeover and abolished the constitution. Fiji was also suspended for the second time from the Commonwealth. ${ }^{1}$

Australia's response was similar to previous coups, insofar as it both condemned the military takeover and called for a return to parliamentary democracy. Yet in the wake of the 2006 coup, Australia's rhetoric toward Fiji intensified. The Howard government was clearly growing tired of the instability brought about by military involvement in Fijian political 
affairs. In "strongly condemning" the coup, Australian Foreign Minister Alexander Downer claimed "[Bainimarama's] takeover of the government is completely unconstitutional and illegal, and cannot be justified on any grounds." "His statements are contrary and wrong," Downer went on to argue, "the Fiji economy, already effected by the military's actions, will be badly damaged, and the people of Fiji will suffer even more" (Downer, 2006). Alongside his condemnation of Bainimarama and his government, Downer announced sanctions against Fiji, imposed travel bans on Bainimarama and his family, and urged the Fijian public to resist his rule. "I think the ordinary people of Fiji and the institutions of government in Fiji should show passive resistance to this imposition of dictatorship on their country," Downer said. He went to outline his view that:

I don't think public servants should cooperate with the commodore and the military. I don't think the police should cooperate ... Bainimarama should understand that there is an urgent need to restore the ownership of government in his country to the people ... through their democratically elected parliament and institutions (Banham, 2006).

Urging domestic resistance against a foreign government was an "unusual" step for an Australian Foreign Minister (Firth, 2013). It perhaps reflected how strongly the Australian government opposed the military coup. Downer's unusual call might also reflect that Fiji was, again, just one $\operatorname{cog}$ in a trend of domestic unrest across the South Pacific that Australia was failing to respond to effectively. Earlier that year, riots had broken out in the Solomon Islands, East Timor, and Tonga. Feeling that Australia was responsible to lead the international response and that Fiji was an important country to respond to first, Howard took aim again at Bainimarama. He described Bainimarama's rule in Fiji as "an undemocratic, arbitrary, peremptory regime." He also urged its Pacific neighbours to press Bainimarama to return Fiji to democracy. Interestingly, emphasis was given to the wider regional context of domestic unrest in which Australia has rejected changes of government in Fiji (Howard, 2007). Contrary to its own objective, Howard's brandish rhetoric appeared to do more to aggravate Bainimarama than to encourage political change, especially after Australia-Fiji relations hit a new low when High Commissioner in Suva James Batley was expelled in late 2009 along with his New Zealand counterpart Michael Green (Merritt, 2009).

Even after several leadership changes in Australia - first with a Labor victory led by Kevin Rudd in the 2007 Federal Election, and then with a Labor leadership spill that saw Rudd's Deputy Prime Minister, Julia Gillard, replace him as Prime Minister from 2010 to 2013-Australia continued to limit its engagement with Bainimarama's regime. A limited engagement strategy certainly demonstrated Australia's distaste for military rule in Fiji, but did not in any way encourage a return to democracy. Rather than explore measures to do so, Australia, along with New Zealand, declined to participate in all forums proposed by Fiji and rejected an invitation to attend a two-day conference on Fiji's progress toward democracy in July 2010. After losing the Prime Ministership to Gillard and becoming Foreign Minister, 
Andrew Kelly

Rudd made a further attack against Fiji's military regime at a Commonwealth Ministerial Action Group Conference in London in May 2011. His comments further isolated Australia from Fiji, with Fiji Foreign Minister Inoke Kubuabola accusing him of "prejudice against Fiji's declared roadmap, so that there is little hope for real re-engagement while Rudd remains in office" (Callick, 2011).

\section{Australia-Fiji Relations under Carr as Foreign Minister}

After Kevin Rudd proved unwilling to change his government's stance on Fiji, his replacement, Bob Carr as Foreign Minister, showed promising signs that Australia was open to normalising relations. Less than two months after his appointment in early March 2012, he visited Fiji after heavy rain and flooding, called for a mass evacuation of Australian tourists. He also visited to discuss the political situation, plans for a 2014 election as well as drafts for a new constitution. Later, along with his New Zealand counterpart Murray McCully, trilateral discussions were held with Kubuabola. These discussions prompted Australia to offer assistance to the upcoming Fijian election as well as the reinstatement of diplomatic relations at the High Commissioner level in Canberra, Wellington and Suva. Efforts such as these epitomised why many government officials, journalists and political commentators saw Carr's appointment as a clear turning point in Australian-Fijian relations. With Carr as Foreign Minister, the Australian government showed "some positive overtones" when these measures were enforced (Kumar, 2013).

At the centre of this change was a keen interest in restoring democracy to Fiji. For Australia, it was both a stabilising factor for the political situation in Fiji but also for the greater South Pacific. Fiji is, after all, a "pivotal state" in the South Pacific and its history of political instability has had serious ramifications for the region (Firth, 2013). It is the Pacific hub for many regional and global organizations-including the Pacific Islands Forum ${ }^{2}$ and the Pacific Office for the United Nations-and, especially for Australia, it is one of the region's most popular tourist destinations. Between 2008 and 2012, Australian tourists accounted for almost half of all Fiji's visitor arrivals, averaging approximately 250,000-300,000 annual visitors (Fiji Bureau of Statistics, 2014). As such, it came as no great surprise when Carr announced that "while there has been some progress in Fiji, I'd like to see a strong trend toward democracy and the rule of law right across the board" (Carr, 2012).

Carr, however, had bigger interests in mind when he spoke about Fiji. Firstly, it provided a means to avoid discussing controversial issues. In his first days as Foreign Minister, he called US Secretary of State Hillary Clinton and "said something about Papua New Guinea and Fiji," rather than discuss "China, ASEAN and grand strategy." A nervous Carr was not yet equipped to tackle such heated issues with arguably the most powerful woman in the world. His next job was to meet her face to face. "I was somewhat nervous," Carr penned in his diary, "aware of my threadbare credentials, about to see a world historical figure with no obvious or specific mission ... where was the beef?" Anxious to avoid embarrassment 
and offer some concrete Australian policies, one of his solutions was to turn to Fiji. "I explained our position on Fiji, firm on sanctions, edging them to a decent constitution and fair election," Carr recalled (Carr, 2014). He would have been glad to hear that Clinton appreciated Australian diplomacy vis-à-vis Fiji and that the United States supported its role in the South Pacific.

Secondly, Carr's keenness to steer Fiji back toward Western liberal values was based at least in part by a strong distaste for Bainimarama, his military and similar regimes around the world. Upon his visit to Fiji in late April 2012, several Fijian businessmen approached Carr and suggested that the current government was working and Australia should relax its harsh stance toward Fiji. His response, framed in broad liberal terms, highlights Carr's view that Fiji's current government not only harms its people, but that:

In the end dictatorships only become lazy, corrupt and brutal. Think of Zimbabwe. You've got to remember that the Commonwealth is a community of democracies. The Pacific Island nations are a community of democracies. There's just no respectable future for a country where military officers rule by decree (Carr, 2014).

In short, Carr had no belief in Bainimarama's rule in Fiji. A stable democracy was the goal, but to achieve this, he was undoubtedly thinking in broader terms. "As bad as it is [in Fiji]," Carr remarked later, "it is doing no more than Singapore did ten or twenty years ago [by] intimidating the opposition [and] bullying the media" (Carr, 2014).

Carr's sweeping generalisation that Fiji, like all other dictatorships, exhibit the same characteristics and behave the same way is grossly simplistic. Military rule has occurred frequently throughout Latin America, Africa and Asia, yet these regimes vary in both their form and content. Fiji is a particularly unique case and one commentator, Jan-Erik Jane, recently made this point clearly. For Lane, Fiji is "not poised for dictatorship" (Lane, 2012; see also Hodge, 2012). Unlike other military ruled countries, Lane argues that Fiji remains well connected to first world countries and relies heavily on trade to Australia and New Zealand. According to World Trade Organization (2013) Australia is Fiji's top export destination (14.8\% of its total exports) and its second highest importer (18.3\% of its total imports).

Moreover, Lane draws correlations between the 2006 coup and its impact on the Fijian economy. GDP growth from 2001 to 2006 averaged approximately $3 \%$, yet in 2007, the economy contracted by a massive $-6.6 \%$. The Reserve Bank of Fiji suggest further decline from 2008-2010, although these statistics have not been verified (Lane, 2012). Alongside growing racial tensions, poverty rates and civilian unrest, military rule in Fiji is thereby not sustainable. In this context, Carr's comments epitomise that Australia had been looking too broadly at dealing with military rule in Fiji. Increasing bilateral dialogue that focused on 
Andrew Kelly

addressing these specific issues and plans for the 2014 election would have done more to achieve Australia's objectives in Fiji than would condemning its government and assuming that Bainimarama will act predictably like other military regimes.

In any case, throughout 2012 Carr grew frustrated at Australia's unsuccessful attempts to change Fiji's political situation. "I was sick of looking at a blank, flickering screen when it came to Fiji," Carr wrote in August. Although he was anything but a fan of military rule, he reasoned it was time to change Australia's Fijian policy because its current approach had achieved nothing since the 2006 military coup. Movement first began in July, after he met with New Zealand Foreign Minister Murray McCully and Fijian Foreign Minister Ratu Inoke Kubuabola in Sydney. The trilateral meeting resulted in agreement over financial assistance for Fiji's 2014 election, as well as restoring a High Commissioner in Canberra, Wellington and Suva. This more flexible approach to Fiji was not a validation of its approval of the current government; to the contrast, Carr made it clear that his government favoured civilian ministers over military officers. It was rather hoped, along with New Zealand, that these measures would encourage Fiji to continue its movement back toward a democratic system.

\section{Australia-Fiji Relations under Abbott's Government}

In September 2013, Tony Abbott won the Australian Federal Election and became Australia's $28^{\text {th }}$ Prime Minister. As part of the incoming government's policy for foreign affairs that was presented to the Parliament in September, promoting democracy in Fiji was one of its major objectives. The policy paper promised to "review the effectiveness of the Fiji sanctions regime" and to "open negotiations" for electoral reforms "as soon as possible." (Australian Liberal Party, 2013). At this early stage, it appeared that the Abbott government was committed to continuing to search for ways in which to repair the Australian-Fijian relationship.

As part of the Coalition's foreign policy review, Abbott's Foreign Minister, Julia Bishop, flew to Suva in February 2014 to meet with Bainimarama in an effort to repair the mutual hostility in Australian-Fijian relations. For too long, at least as far as Bishop and the Coalition was concerned, Australia had isolated Fiji and done little to change the political situation. Bishop's goal was to provide a fresh start for her government with respect to Fiji after the Howard-Rudd-Gillard years favoured political sanctions, particularly in the context of the upcoming election. Bishop suggested she "want to normalise relations ahead of an election" and "wants Australia to be the partner of choice in the Pacific ... there is an opportunity with our new government to start afresh" (Callick, 2014). In other words, she wanted to bring Fiji "out of the cold."

There were certainly dangers in such a move. There was no certainty that normalising relations with Fiji would lead to a peaceful transition back into democracy in September 2014. After all, even after vehement Australian protestations against the legitimacy of 
his rule, Bainimarama has kept his control over Fiji since 2006. Bainimarama had also previously delayed movement toward an election in 2009 , when it was originally planned to take place. Because of this, there were strong suggestions that "any election that is held cannot be free and fair" and that "the early signs [for an election] do not inspire confidence (Lal and Hunter, 2012).

Nevertheless, it was crucial that the Abbott government made at least some progress in repairing Australian-Fijian relations. Normalising relations with Fiji provided one important opportunity for the Coalition to demonstrate it had a positive plan for Australia's engagement with the world. It distanced itself from past ineffectual Labor policies, while simultaneously promoted Western democratic values and systems in one of Australia's key strategic regions. Its first step, lifting travel sanctions on Bainimarama, his family and other government officials was an "overdue" and "decisive step" and (Callick, 2014; Bergin, 2014). Bishop's visit was another positive step in the right direction.

Overall, these efforts lent a useful hand in staging a successful election in Fiji in September 2014. Amongst other nations, Australia took up an invitation to observe the election. Moreover, two Australians worked with the Fijian Elections Office as Deputy Supervisor and Director of Operations that ensured the election ran smoothly and fairly. As far as the actual election results were concerned, Bainimarama in fact led the Fiji First Party, to victory by a comfortable margin. In coming years, it will be interesting to see just how Australia deals with the Bainimarama government now that it holds a more legitimate right to govern in Fiji.

\section{Conclusion}

In each of Fiji's coups in 1987, 2000 and 2006, Australia failed to strike an appropriate balance between simultaneously condemning a military takeover and taking positive steps toward restoring Fiji to normal democratic processes. Previous condemnatory policies under the Hawke and Howard governments, which tended to view Fiji through a broad strategic lens, did little to encourage political change in Suva. Recent positive steps by Bob Carr and the Abbott government have inspired some degree of confidence about the future of Fiji and its relationship with Australia. Nevertheless, for Australia to find long-term stability in Fiji, the Abbott government must learn from past mistakes, tread cautiously, and encourage stronger dialogue between the two countries.

\section{End Notes}

1 Fiji was originally suspended only from membership on the Councils of the Commonwealth in December 2006. Once Bainimarama solidified military rule and abolished the constitution in 2009, Fiji was suspended fully from the Commonwealth. This excluded Fiji from all Commonwealth meetings, sporting events, and assistance programs. 
Andrew Kelly

2 The Pacific Islands Forum is the most important regional organisation in the South Pacific. The forum's objective is to "stimulate economic growth and enhance political governance and security for the region." After Bainimarama failed to hold an election in 2009, Fiji became the first ever nation to be suspended from the organisation (see http://www.forumsec.org/pages.cfm/about-us/missiongoals-roles/, accessed 10 April 2014).

\section{References}

Alley, R. (2010). Fiji under Bainimarama: Brave new world or hostage to perdition? The Journal of Pacific History, 45 (1), 145-153.

Australian Liberal Party. (2013, September). The coalition's policy for foreign affairs. Retrieved from http://parlinfo.aph.gov.au.

Ayson, R. (2007). The 'Arc of Instability' and Australia's strategic policy. Australian Journal of International Affairs, 61 (2), 215-231.

Banham, C. (2006, December 7). Downer urges passive resistance. Sydney Morning Herald. Bainimarama, F. (2006, December 6). Voreqe Bainimarama's press statement. Fiji Times, Retrieved from http://www.fijitimes.com/extras/TakeOverAddress.pdf.

Bergin, A. (2014, April 1). Fijian military natural choice for brothers in arms across Pacific. The Australian.

Brown, W. (1987, October 14). Leaders ease hostility to Rabuka regime. Courier Mail.

Cain, T.( 2014). Fiji: A flurry of election activity. Sydney: Lowy Institute for International Policy.

Callick, R. (2011, May 10). Fiji foreign minister calls Rudd prejudiced. The Australian.

Callick, R. (2014, February 15). Julie Bishop move to bring Fiji in from cold. The Australian.

Carr, B. (2012). Response to Fiji Coup. Media release, 17 April. Retrieved from http:// foreignminister.gov.au/releases/Pages/2012/bc_mr_120417.aspx?ministerid=1.

Carr, B. (2014). Diary of a foreign minister. Sydney: University of New South Wales Press.

Downer, A. (2006, December 6). Response to Fiji Coup. Media release. Retrieved from http://www.foreignminister.gov.au/releases/2006/fa135_06.html.

Dunan, R., \& Chand, S. (2002). The economics of the 'Arc of Instability'. Asian-Pacific Economic Literature, 16 (1), 1-9.

Fiji Bureau of Statistics. (2014). Visitor arrivals by country of residence. Retrieved from http://www.statsfiji.gov.fj/index.php/migration-a-tourism/10-migration-statistics/ migration-a-tourism/115-visitor-arrivals-statistics.

Firth, S. (2013). Australia's policy toward coup-prone and military regimes in the AsiaPacific: Thailand, Fiji and Burma. Australian Journal of International Affairs, 67 (3), 357-372.

Fraenkal, J. (2013). The origin of military autonomy on Fiji: A tale of three coups. Australian Journal of International Affairs, 67 (3), 327-341.

Fraenkal, J., \& Firth, S. (2007). From election to coup in Fiji: The 2006 coup and its aftermath. Canberra: Australian National University Press. 
Fraenkal, H. et al. (Eds). (2009). The 2006 military takeover in Fiji: A coup to end all coups? Canberra: Australian National University Press.

Hartcher, P. (2013, September 4). I would be an 'Asia-first' Prime Minister, says Abbott. Sydney Morning Herald.

Hawke, R. (1994). The Hawke memoirs. Sydney: Random House.

Hayward-Jones, J. (2014). Fiji: An election in 2014 and Bainimarama will stand. Sydney: Lowy Institute for International Policy.

Hayward-Jones, J. (2011). Policy overboard: Australia's increasingly costly Fiji drift. Sydney: Lowy Institute for International Policy.

Hodge, P. (2012). A progressive authoritarianism? The case of post-2006 Fiji. Third World Quarterly, 33 (6), 1147-1163.

Howard, J. (2007, June 15). Joint press statement with Helen Clark. Sydney.

Howard, M. (2011). Fiji: Race and politics in an Island state. Canada: University of British Columbia Press.

House of Representative Debates. (1987). Parliament of Australia, Canberra.

Hywood, G. et al. (1987, October 14.). Hawke may recognise Rabuka. Australian Financial Review.

Kumar, A. (2013). Lessons of experience in international democratic promotion: The case of Australia in post-coup Fiji. Journal of Pacific Studies, 33 (1), 62-77.

Lal, B. (2012). Fiji's coup conundrum. The Round Table: The Commonwealth Journal of International Affairs, 101 (5), 489-497.

Lal, B. (2010). In the eye of the storm: Jai Ram Reddy and the politics of postcolonial Fiji. Canberra: Australian National University Press.

Lal, B., \& Pretes, M. (Eds). (2008). Coup: Reflections on the political crisis in Fiji. Canberra: Australian National University Press.

Lal, V., \& Hunter, R. (2012). Frank Bainimarama's tiger and Fiji election prospects in 2014. The Round Table: The Commonwealth Journal of International Affairs, 101 (5), 463-465.

Lane, J. (2012). Fiji: What kind of militocracy? Japanese Journal of Political Science, 13 (3), 401-417.

Merritt, C., \& Waters, P. (2009, November 4). Fiji expels high commissioner. The Australian. Prime Minister's Office. (1987). Media release on Fiji. Canberra.

Robertson, R. (2012). Cooking the goose: Fiji's coup culture contextualised. The Round Table: The Commonwealth Journal of International Affairs, 101 (6), 509-519.

Rumley, D. et al. (Eds). (2006). Australia's Arc of instability: The political and cultural dynamics of regional security. Netherlands: Springer.

Sargent, S., \& Davies, A. (1987, October 15). Strategic factors spur PM. Australian Financial Review.

Senate Debates. (1987). Parliament of Australia, Canberra.

World Trade Organisation. (2013). Trade flows and policy measures. Retrieved from http:// www.wto.org/english/res_e/booksp_e/trade_profiles13_e.pdf. 